\title{
Use of Knowledge System in the Rural Community in Improving Livelihood Status of the Farmers under RDRS
}

\author{
M.S. ISLAM ${ }^{1 *}$, M.E. UDDIN ${ }^{2}$ AND M.U. RASHID ${ }^{3}$ \\ ${ }^{1}$ Dept. of Agril. Extension Education, Bangladesh Agricultural University, Mymensingh, Bangladesh \\ ${ }^{2 \& 3}$ Dept. of Agril. Extension and Rural Development, Patuakhali Science and Technology \\ University, Dumki, Patuakhali, Bangladesh
}

\begin{abstract}
The study was focused to determine the extent of use of knowledge system in improving livelihood status of the farmers. The relationship between selected characteristics of the farmers and extent of use of knowledge system in improving their livelihood status was also explored. The study was conducted in Raipur Union of Thakurgaon Sadar Upazila under Thakurgaon District. The population of the study was 146 and seventy percent of the population was selected at random and as such 101 farmers were selected as sample. Data were collected through interview schedule by the researcher himself during 07 February to 28 March 2004. The majority (69 percent) of the respondents possessed medium extent of knowledge while 17 percent low and 14 percent possessed high extent of knowledge on livelihood. Out of thirteen selected characteristics of the respondents level of literacy, farm size, and annual income, farming and living expenditure, innovativeness, communication exposure, cosmopoliteness, organizational participation, aspiration and fatalism had positive significant relationship with the extent of use of knowledge system in improving livelihood status.
\end{abstract}

Key words: Information system, livelihood status, farmers.

\section{INTRODUCTION}

The term Agricultural Knowledge Systems was coined by Coombs and Ahmed in 1974. Knowledge is something between the ears, a property of the mind, which cannot be heard, seen or touched (RÖling and Engel, 1991). The idea of knowledge dissemination and utilization in a systems context was proposed by Havelock (1971). Chamala and Coughenour (1987) also mentioned government policies as an exogenous variable that determine the success of the system for agricultural development. This is identified as one of the key pressures acting on the knowledge and information system (KIS) in the agriculture sector. However the KIS institutions must receive stronger and focused external pressure to function synergically over sustained periods and examines the roles of policy makers, foreign agencies, farmers and the private sector in pressuring KIS institutions. To take full advantage of technology, the extent of knowledge in agriculture should be considered as a system.

\footnotetext{
* Corresponding author: Former MS student, Dept. of Agricultural Extension Education, BAU, Mymensingh

(C) 2006 School of Agriculture and Rural Development, Bangladesh Open University, All rights reserved.
} 
All farmers of Bangladesh are involved mainly in rice production, which covers more than 75 percent of the total cultivated land. Unfortunately, the average yield per unit area ( $3 \mathrm{mt} / \mathrm{ha})$ is far below the potential yield ( $7 \mathrm{mt}$. /ha). This is due to such factors as inadequate use of knowledge and information system on quality inputs and insufficient and ineffective post harvest operations and storage facilities of agricultural products. In addition, due to the lack of appropriate knowledge on various aspects of production viz. soil fertility, productivity, quality seed, fertilizer, irrigation, HYV seed, different types of HYV crops, marketing system etc. and lack of knowledge on livestock, poultry, fisheries, health, education and other issues relating to agriculture as well as livelihood, the production remained as low. So, regarding the present situation of Bangladesh, it is not possible to improve the status of rural livelihood of farmers without improving the core sector "agriculture" through the use of improved knowledge system.

The RDRS (Rangpur Dinajpur Rural Service) Bangladesh targets the rural people to reduce their sufferings from different aspects of their life through technical knowledge and appropriate information system to achieve economic solvency and they deem that will lead them towards all round development. The development of people means development in all spheres of life, which is normally termed as total livelihood development. However, no systematic investigation has so far been undertaken on this issue in Bangladesh. This study, thus takes initiatives to address the extent of use of knowledge system and its impact on their socioeconomic development in improving livelihood status of farmers.

\section{MATERIALS AND METHODS}

The study was conducted in Raipur union of Sadar Upazilla under Thakurgoan district where knowledge and information system (KIS) project was being implemented by RDRS; this was being implemented in different villages of Raipur Union by organizing ten (10) groups. The present study was conducted in ten (10) groups including five male and five female groups. In order to identify the population for the study a list of KIS group member was collected from the RDRS extension worker known as KIS team member. The entire KIS group members were considered as the population of this study. In this project total 146 farmers were directly involved dividing in 10 groups. The groups were popularly known as KIS groups. Each group has a farmer promoter and a co-promoter within the group members. Seventy percent farmers from the KIS group members were randomly selected by simple random sampling method (Kerlinger, 1973). In this way 50 male farmers and 51 female farmers were selected as sample from five male groups and five female groups. Thus, the sample size of the research was 101. Data were collected during 07 February to 28 March 2004.

The dependent variable of the investigation was extent of use of knowledge system in improving livelihood status of the farmers under RDRS. The independent variables of this study were 13 selected characteristics of the farmers of KIS group. These were age, level of literacy, family size, farm size, annual income, farming and living expenditure. Innovativeness, decision making ability, communication exposure, cosmopoliteness, organizational participation, aspiration and fatalism. Extent of use of knowledge system in improving livelihood status of a respondent was measured on the basis of their use of different kind of knowledge sources. Farmer's knowledge on livelihood of respondents was measured by making the correct responses of 58 different kinds of questions in relation to various aspects of livelihoods. It was measured in score. The assigned score of each question was not equal. It was calculated according to the nature of questions and answers. The total assigned score of all the questions was 120. A respondent answering a question correctly obtained full scores while for wrong answer he/she obtained zero score. There were some answers which were scored in between zero to full score assigned according to the grade of responses obtained. Each of the questions has one, two or three marks and for correct response, a respondent was given full marks $(1,2$ or 3$)$ and 1.5 or 2.5 for partially correct answer while 0 for the wrong answer or no answer. The summation of marks obtained by a respondent was the knowledge score of the respondent. The knowledge on livelihood score could range from 0 to 120 , where 0 indicating no knowledge and 120 indicating very high knowledge on livelihood. 
Use of Knowledge System in the Rural Community in Improving Livelihood Status of the Farmers

\section{RESULTS AND DISCUSSION}

\section{Use of knowledge system in improving livelihood status of the farmers}

Observed knowledge scores on livelihood of farmers ranged from 42 to 106 against the possible range of 0 to 120 . The average and standard deviation were 66.81 and 14.75 respectively. Based on the knowledge scores, the respondents were classified into three categories as shown in Table 2. Data contained in Table 2 indicates that the majority (69 percent) of the respondents was medium user of knowledge system compared to 17 percent having low user and 14 percent high user of knowledge system. It reveals that the majority (83 percent) of the respondents in the study area were in medium to high user categories of knowledge system. Adequate knowledge is essential for improving rural livelihood of farmers. General performance of the respondents in their knowledge test could be well compared with the studies of Hossain (2000). The number of test items in Hossain's study was 25 items in his study. In the present study the number of test was 52. Nurzaman (2000) also found similar kind of results in his study.

\section{Selected characteristics of the farmers}

A summary of thirteen selected characteristics of the farmers has been presented in the Table 1 . The information of Table-1 indicates that majority of the farmers (60 percent) were young aged and highest proportion (84 percent) of them had primary level of literacy. Medium sized family is dominant in the locality. On the other hand, majority of the farmers had small to medium size farm. Most of the farmers belong to low income group. Data also indicate that majority of the farmers had medium to low income. Farming and living expenditure were also medium to low in the rural community. The farmers were medium in innovativeness and decision making ability. Their communication exposure and cosmopoliteness were medium to low and organizational participation was low which could act as a barrier to their extent of use of knowledge system on livelihood. On the other hand they were medium to highly aspirated and moderate fatalistic. Aspiration in farming as well as on livelihood likely to makes a man innovative and hard working to acquire knowledge and information in farming activities and relating to livelihood. Fatalistic persons lack knowledge and information to make satisfactory adjustment to their environment. They are generally non-adapters to new ideas about knowledge and information system.

\section{Relationship between selected characteristics of the farmers with their use of knowledge system in improving livelihood}

The summary of the correlation test between selected characteristics of the farmers and their extent of use of knowledge system in improving livelihood status are shown in the Table 3. Out of thirteen selected characteristics of the farmers, education, family size, farm size, annual income, farming and living expenditure, innovativeness, communication exposure, organizational participation and, aspiration were positively correlated with their use of information system. But only four variables i.e. age, decision making ability, cosmopoliteness and fatalism had no significant relationship with the use of knowledge system in improving their livelihood (Table 3).

Age of the farmers is not an important factor in gaining knowledge on livelihood. Education helps an individual to gain knowledge and improve skill. Educated person become conscious about expectation which ultimately enhance the individual to become more rational. An educated person is usually cosmopolite and innovative. Large size family acts as a barrier in gaining knowledge. Innovativeness is a psychological factor that influences a person to expose to different information sources and consider for its adoption earlier than the other members of the society. Aspiration in farming as well as on livelihood likely to make a man innovative and hard working to acquire knowledge and information in farming matters and relating to livelihood but fatalism acts as a barrier in gaining knowledge and improving livelihood status. Participation in different organizations would provide a person to gain knowledge and information and ultimate result is change in livelihood status. 
M.S. Islam et al.

Table 1. Salient feature of the respondents' with their characteristics

\begin{tabular}{|c|c|c|c|c|c|c|c|c|}
\hline \multirow[b]{2}{*}{ Characteristics } & \multirow{2}{*}{$\begin{array}{l}\text { Scoring } \\
\text { system }\end{array}$} & \multicolumn{2}{|c|}{ Range } & \multirow[b]{2}{*}{ Category } & \multicolumn{2}{|c|}{ Respondents } & \multirow[b]{2}{*}{ Mean } & \multirow{2}{*}{$\begin{array}{l}\text { Standard } \\
\text { deviation }\end{array}$} \\
\hline & & Possible & Observed & & $\begin{array}{l}\text { Number } \\
(\mathrm{N}=101)\end{array}$ & Percent & & \\
\hline \multirow{3}{*}{ Age } & \multirow{3}{*}{ Years } & & \multirow{3}{*}{$\begin{array}{l}0 \\
0 \\
\infty \\
1 \\
-1\end{array}$} & Young (18-35) & 60 & 59.4 & \multirow{3}{*}{34.76} & \multirow{3}{*}{9.22} \\
\hline & & & & Middle-aged (36-45) & 33 & 32.6 & & \\
\hline & & & & Old $(\geq 46)$ & 8 & 7.92 & & \\
\hline \multirow{3}{*}{ Level of literacy } & \multirow{3}{*}{$\begin{array}{l}\text { Level of } \\
\text { schooling }\end{array}$} & & $\dot{J}$ & Primary (upto class V) & 84 & 83 & \multirow{3}{*}{3.29} & \multirow{3}{*}{3.68} \\
\hline & & & மे & Secondary $(6-10)$ & 12 & 11.88 & & \\
\hline & & & 0 & Above secondary $(>10)$ & 5 & 4.59 & & \\
\hline \multirow{3}{*}{ Family size } & \multirow{3}{*}{ Numbers } & & \multirow{3}{*}{ 六 } & Small (2-4) & 32 & 31.68 & \multirow{3}{*}{5.65} & \multirow{3}{*}{2.25} \\
\hline & & & & Medium (5-8) & 61 & 60.40 & & \\
\hline & & & & Large $(\geq 9)$ & 8 & 7.92 & & \\
\hline \multirow{4}{*}{ Farm size } & \multirow{4}{*}{ Hectares } & & $\mathscr{q}$ & Marginal $(0.20-0.60)$ & 34 & 34.00 & & \\
\hline & & & קి & Small (0.61-1.00) & 25 & 25.00 & & \\
\hline & & & 욱 & Medium (1.01-3.00) & 40 & 39.60 & 0.96 & 0.18 \\
\hline & & & 0 & Large $(>3.00)$ & 2 & 2.00 & & \\
\hline & & & 오 & $\operatorname{Low}(\leq 50)$ & 52 & 51.48 & & \\
\hline Annual income & $\begin{array}{l}\text { Unit score } \\
\text { (taka) }\end{array}$ & & $\infty$ & Medium (51-100) & 39 & 38.61 & 57.49 & 38.36 \\
\hline & & & $\stackrel{+\infty}{\sim}$ & High $(\geq 101)$ & 10 & 9.90 & & \\
\hline Farming and & & & i & $\operatorname{Low}(\leq 50)$ & 82 & 81.18 & & \\
\hline living & Unit score & & ํ. & Medium (51-100) & 18 & 17.82 & 33.13 & 21.44 \\
\hline expenditure & & & & $\operatorname{High}(\geq 101)$ & 1 & 0.99 & & \\
\hline & & & & $\operatorname{Low}(\leq 21)$ & 16 & 15.84 & & \\
\hline Innovativeness & $\begin{array}{l}\text { scale } \\
\text { score }\end{array}$ & م & Ý & Medium (22-34) & 77 & 76.23 & 26.97 & 6.20 \\
\hline & & & & High $(\geq 35)$ & 8 & 7.92 & & \\
\hline & & & $\hat{\Omega}$ & $\operatorname{Low}(\leq 13)$ & 24 & 23.76 & & \\
\hline $\begin{array}{l}\text { ability } \\
\text { ang }\end{array}$ & $\begin{array}{l}\text { Rated } \\
\text { score }\end{array}$ & î & N1 & Medium (14-18) & 73 & 72.27 & 15.42 & 2.62 \\
\hline & & & $\vec{r}$ & High $(\geq 19)$ & 4 & 3.96 & & \\
\hline & & & & $\operatorname{Low}(\leq 10)$ & 15 & 14.85 & & \\
\hline exposure & $\begin{array}{l}\text { Rated } \\
\text { score }\end{array}$ & مִ & $\underset{1}{N}$ & Medium (11-16) & 75 & 74.25 & 12.65 & 3.15 \\
\hline & & & & $\operatorname{High}(\geq 17)$ & 11 & 10.89 & & \\
\hline & & & & $\operatorname{Low}(\leq 4)$ & 33 & 32.67 & & \\
\hline Cosmopoliteness & $\begin{array}{l}\text { Rated } \\
\text { score }\end{array}$ & ન્ન & ㄱ.- & Medium (5-7) & 61 & 60.39 & 5.32 & 1.61 \\
\hline & & & & High $(\geq 10)$ & 7 & 6.93 & & \\
\hline & & & & No participation (0) & 0 & 0 & & \\
\hline Organizational & Rated & $\stackrel{\mathscr{Y}}{\mathscr{V}}$ & $\overbrace{1}$ & Low participation (1-10) & 101 & 100.00 & 145 & 106 \\
\hline participation & score & o & 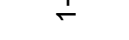 & Medium participation (11-25) & 0 & 0.00 & 1.45 & 1.06 \\
\hline & & & & High participation $(>25)$ & 0 & 0.00 & & \\
\hline & & & & Low (3-10) & 36 & 35.64 & & \\
\hline Aspiration & $\begin{array}{l}\text { Rated } \\
\text { score }\end{array}$ & N̦ & 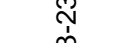 & Medium (11-15) & 28 & 27.72 & 13.66 & 5.22 \\
\hline & & & & High (16 and above) & 37 & 36.63 & & \\
\hline & & & g & Low (20-27) & 23 & 22.77 & & \\
\hline Fatalism & $\begin{array}{l}\text { Rated } \\
\text { score }\end{array}$ & กิ & ơ & Medium (28-37) & 71 & 70.29 & 31.63 & 5.10 \\
\hline & & 0 & $\sim$ & High (38 and above) & 7 & 6.93 & & \\
\hline
\end{tabular}

Table 2. Distribution of the farmers according to their use of knowledge system

\begin{tabular}{|c|c|c|c|c|c|c|c|c|}
\hline \multirow[b]{2}{*}{ Characteristics } & \multirow{2}{*}{$\begin{array}{l}\text { Scoring } \\
\text { system }\end{array}$} & \multicolumn{2}{|c|}{ Range } & \multirow[b]{2}{*}{ Category } & \multicolumn{2}{|c|}{ Respondents } & \multirow[b]{2}{*}{ Mean } & \multirow{2}{*}{$\begin{array}{l}\text { Standard } \\
\text { deviation }\end{array}$} \\
\hline & & Possible & Observed & & $\begin{array}{l}\text { Number } \\
(\mathrm{N}=101)\end{array}$ & Percent & & \\
\hline $\begin{array}{c}\text { use of } \\
\text { knowledge } \\
\text { system }\end{array}$ & $\begin{array}{l}\text { Rated } \\
\text { Score }\end{array}$ & $0-120$ & $42-106$ & Low $(\leq 52)$ & 17 & 16.83 & 66.81 & 14.75 \\
\hline
\end{tabular}


Use of Knowledge System in the Rural Community in Improving Livelihood Status of the Farmers

Table 3. Correlation coefficient between selected characteristics of farmers with their use of knowledge system in improving their livelihood status

\begin{tabular}{lccc}
\hline Characteristics of the farmers & $\begin{array}{c}\text { Correlation coefficient }(r) \text { with use of } \\
\text { knowledge system in improving livelihood }\end{array}$ & \multicolumn{2}{c}{ Table value significant at } \\
\cline { 3 - 4 } & $0.042^{\mathrm{NS}}$ & 0.05 level & 0.01 level \\
\hline \hline Age & $0.365^{\star *}$ & \\
level of literacy & $0.161^{\mathrm{NS}}$ & \\
Family size & $0.294^{\star *}$ & \\
Farm size & $0.367^{\star *}$ & \\
Annual income & $0.309^{\star *}$ & \\
Farming and living expenditure & $0.517^{\star *}$ & \\
Innovativeness & $-0.150^{\mathrm{NS}}$ & \\
Decision making ability & $0.592^{\star *}$ & \\
Communication exposure & $0.268^{\star *}$ & \\
Cosmopoliteness & $0.392^{\star *}$ & \\
Organizational participation & $0.606^{\star *}$ & \\
Aspiration & $0.420^{\star *}$ & \\
Fatalism & & \\
\hline
\end{tabular}

* Significant at $p<0.05 ; * *$ Significant at $p<0.01 ; \mathrm{NS}=$ Not-significant

Farmers with large farm size use different types of knowledge sources and systems for intensive cultivation and scope are created in improving their livelihood status. Farmers with higher income had better economic and social status in the community. This help them to increase extent of use of knowledge system in improving livelihood. Farmers with higher expenditure had better economic and social status in the community, which makes them mobile and cosmopolite and also increase his communication exposure which ultimately contributes to the extent of use of knowledge system more efficiently by the farmers. Farmers with higher extent of use of knowledge system had higher aspiration. So, aspiration is an important factor in using knowledge system in rural community in improving the livelihood status of farmers. Fatalism acts as a barrier in using higher extent of knowledge system in improving rural livelihood of farmers.

\section{CONCLUSION}

The extent of use of knowledge system is an important factor for improving rural livelihood of farmers in a rural community. The findings of the study revealed that majority (83 percent) of the farmers were medium to high user of knowledge system. It may due to the fact that all of the respondents are involved in RDRS activities and received training from RDRS on different aspects of livelihood especially on income generating activities. At the same time they received training from DAE, youth development department and other such organizations arranged by RDRS. These training increased farmers' knowledge and awareness on improved livelihood and status in the rural community. Knowledge on livelihood of the farmers had significant positive relationship with their education, farm size, annual income, farming and living expenditure, innovativeness, communication exposure, cosmopoliteness, organizational participation, aspiration and fatalism while decision making ability of the respondents had negative insignificant relationship with the extent of use of knowledge system on livelihood. Therefore, it may concluded that the factors related to farmers knowledge should be carefully considered and necessary steps should be taken to improve the overall knowledge status. The findings of the study lead to the following recommendations:

1. The concerned authority should undertake educational activities for improving the literacy level of the farmers. It will also helpful to increase level of aspiration and reduce fatalism.

2. Credit facilities and training programs on IGAs (Income Generation Activities) should provide for the respondents to upgrade their level of living.

3. DAE and RDRS should take necessary steps to increase the opportunities of the respondents to visit different organizations and places of agricultural importance because cosmopoliteness is a significant factor for knowledge development. 


\section{M.S. Islam et al.}

4. Planned communication exposure with more effective media should be launched with the client system as communication exposure is important for developing knowledge.

5. Need based training programs should be developed and implemented extensively by different service providing organizations to improve the status of living of the farmers in the rural community.

\section{LITERATURE CITED}

Chamala, S. and Coughenour, M. C. 1987. Model for Innovation Development Diffusion and Adoption. A system for Agricultural Development. Journal of Extension Systems. 3(1), 47-55.

Coombs, P. H. and Ahmed, M. 1974. Attacking Rural Poverty How Non Formal Education can Help. London: John Hopkin University Press.

Havelock, R. G. 1971. Planning for Innovations through Dissemination and Utilization of Knowledge. Michigan: Institute of Social Research, University of Michigan.

Hossain, S. M. 2000. Farmers' Knowledge and Perception of Binadhan-6. M.S. (Ag.Ext.Ed.) Thesis, Department of Agricultural Extension Education, Bangladesh Agricultural University, Mymensingh.

Kerlinger, F. N. 1973. Foundations of Behavioural Research. 2nd Edn. New York: Holt, Rinehart and Wiston. Inc.

Nurzaman, M. 2000. Knowledge, attitude and practice of FFS farmers in respect of IPM. M.S. (Ag.Ext.Ed.) Thesis, Department of Agricultural Extension Education, Bangladesh Agricultural University, Mymensingh.

Rolling, N. G. and Engel, P. G. H. 1991. IT from a knowledge system perspective: concepts and issues. In: Kuiper, D. and Roling, N.G. (eds). The edited proceedings of the European Seminar on Knowledge Management and Information Technology. Wageningen: Agricultural University: 8-20. 